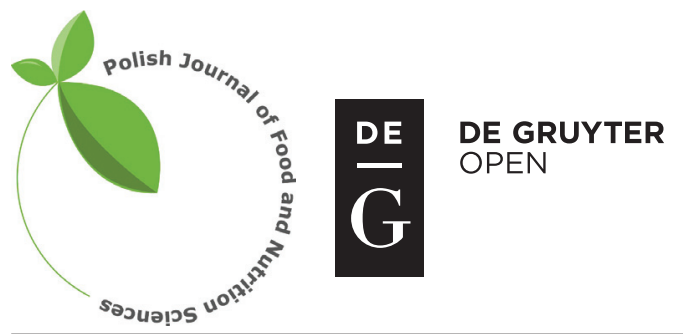

Pol. J. Food Nutr. Sci., 2018, Vol. 68, No. 4, pp. 347-358

DOI: $10.1515 /$ pjfns-2018-0008 http://journal.pan.olsztyn.pl

Original research article

Section: Food Quality and Functionality

\title{
Emulsifying Properties of Dried Soy-Whey, Dried Tofu-Whey, and Their Isolated Proteins
}

\author{
Pablo A. Sobral ${ }^{1}$, J. Sebastian Henao Ossa ${ }^{2}$, Gonzalo G. Palazolo ${ }^{2,3 *}$, Jorge R. Wagner ${ }^{2,3}$ \\ ${ }^{1}$ Universidad Nacional de La Plata, Facultad de Ciencias Exactas. Calle 47 (s/n) y 115 (1900), \\ La Plata, Provincia de Buenos Aires, Argentina \\ ${ }^{2}$ Universidad Nacional de Quilmes, Departamento de Ciencia y Tecnología, Pabellón Dra. María Cristina Taira, \\ Laboratorio de Investigación en Funcionalidady Tecnología de Alimentos (LIFTA). Roque Sáenz Peña 352 (B1876BXD), \\ Bernal, Provincia de Buenos Aires, Argentina \\ ${ }^{3}$ Consejo Nacional de Investigaciones Científicas y Técnicas (CONICET), Buenos Aires, Argentina
}

Key words: isolated proteins, o/w emulsions, soy-whey, stability, tofu-whey

This paper focuses on the comparative study of emulsifying properties of dried tofu-whey, dried soy-whey and their isolated proteins. Oil-in-water emulsions were prepared at equivalent protein concentration $(0.1,0.5$ and $1.0 \mathrm{~g} / 100 \mathrm{~mL})$, using sunflower oil as lipid phase (oil mass fraction $=0.33$ ). Tofu-whey and soy-whey were dehydrated by freeze-drying (LTW and LSW, respectively) or thermal-drying (DTW and DSW, respectively). Moreover, a heated LSW sample in anhydrous condition (h-LSW) was included. The emulsion formation and stability at rest was evaluated using a vertical scan analyzer, according to multiple light scattering theory, particle size and oiling off measurements. Even though the stability to gravitational separation and coalescence increased with increasing protein concentration, freeze-dried whey samples exhibited a higher ability to form and stabilize emulsions respect to that of thermally-dried ones, especially for those obtained from soy-whey. Moreover, h-LSW emulsions were more stable than that of LSW sample presumably due to protein glycosylation. The global emulsion stability decreased in the order: LTW $>$ DTW $>h-L S W>$ LSW $>$ DSW. Moreover, at equivalent protein concentration in the continuous phase, the isolation of proteins from lyophilized whey-samples by treatment with cold acetone (LTW-P, LSW-P and h-LSW-P, respectively) improved their emulsifying properties. Again, this improvement was more pronounced for samples obtained from soy-whey, probably due to partial protein denaturation associated to treatment with the organic solvent. In conclusion, this paper should be considered as basis for further studies concerned with the potential application of soy-whey and tofu-whey proteins as emulsifiers in different systems.

\section{ABBREVIATIONS}

BBTI: Bowman-Birk trypsin inhibitor; BS: backscattering; $\mathbf{B S}_{\text {bottom }}$ : mean value of backscattering at the bottom of the measurement cell; $\mathbf{B S}_{0 \text {, bottom }}$ : initial $(\mathrm{t}=0)$ mean value of backscattering at the bottom of the measurement cell; $\mathbf{B S}_{\text {top }}$ : mean value of backscattering at the top of the measurement cell; $\mathbf{C H} / \mathbf{P}_{\mathrm{T} \text {-TCA }}$ : carbohydrate-protein mass ratio in the total aqueous dispersion; $\mathbf{C H} / \mathbf{P}_{\text {S-TCA }}$ carbohydrate-protein mass ratio in the soluble aqueous dispersion; $\mathbf{D}_{43}$ : De Brouckere, volume-weighted mean diameter; $\mathbf{D}_{4,3-\text { sDs }}$ : De Brouckere, volume-weighted mean diameter measured in the absence of sodium dodecyl sulfate; $\mathbf{D}_{4,3+\text { SDS }}$ : De Brouckere, volume-weighted mean diameter measured in the presence of sodium dodecyl sulfate; $\mathbf{K}$ : gravitational separation kinetic constant; KTI: Kunitz trypsin inhibitor; SDS: sodium dodecyl sulfate; TCA: trichloroacetic acid; TIA: trypsin inhibitor activity; r-TIA: relative trypsin inhibitor activity; Vr: relative cream layer volume.

\footnotetext{
* Corresponding Author: Tel.: +54 1143657100 (int. 5415); Fax: +54-11-4365 7132;

E-mail address: gonzalo.palazolo@unq.edu.ar (G.G. Palazolo)
}

\section{INTRODUCTION}

Soy-whey is the residual liquid generated after isoelectric precipitation of storage soy proteins (conglycinin, $\beta$-conglycinin) during the industrial manufacture of soy protein isolate. Soy-whey contains various useful compounds such as proteins, oligosaccharides, polysaccharides and soy isoflavones [Liu et al., 2013; Ray \& Rousseau, 2013; Singh \& Banerjee, 2013]. The main proteins present in this residual liquid, all soluble in a wide $\mathrm{pH}$ range, are the Kunitz and Bowman-Birk trypsin inhibitors, the lectin or hemagglutinin and other minor proteins such as $\beta$-amylase, urease and lipoxygenase [Sobral \& Wagner, 2007; Ray \& Rousseau, 2013]. The trypsin inhibitors and lectin, in a native state, exert a negative impact on the nutritional quality of proteins, and hence are the major antinutritional factors present in soybean [Huang et al., 2008; Vagadia et al., 2017]. In industry, the biological treatment of soy-whey considerably increases the cost of the production of soy protein isolates. The loss of the soy-whey proteins results in a water pollution problem [Kasran et al., 2013]. Nevertheless, if the valuable compounds of soy-whey wastewater are recovered using appropriate methods, it will be profitable for plants producing soy protein isolates [Li et al., 2014]. In ad- 
dition, the activity of trypsin inhibitors and lectin can be destroyed by thermal treatments, leading to irreversible protein denaturation. The extent of inactivation is a function of temperature, duration of heating, particle size and moisture conditions. Most commercial soybean products have received sufficient heat treatment to cause inactivation of at least $80-90 \%$ of the trypsin inhibitor activity present in raw soybeans [Lajolo \& Genovese, 2002; van der Ven et al., 2005; Huang et al., 2008; Vagadia et al., 2017]. Indeed, the thermal treatment on dehydrated soy-whey above $140^{\circ} \mathrm{C}$ in anhydrous conditions induces a total denaturation of Kunitz trypsin inhibitor and lectin and a decrease of antitryptic activity until residual levels [Sobral \& Wagner, 2007]. Therefore, the thermal treatment on dehydrated soy-whey in anhydrous conditions would also be an interesting alterative to inactive the antinutritional factors. This strategy would reduce the costs associated to the thermal treatments of high amount of liquid samples.

On the other hand, tofu is the main processed soybean edible product in the world. This product is prepared by adding coagulants such as calcium salts and organic acids to soymilk to precipitate the protein and oil into a gelatinous curd [Benedetti et al., 2015; Shen \& Kuo, 2017]. Tofu-whey is the liquid by-product generated during the soybean curd processing. As in soy-whey, tofu-whey contains a high content of valuable nutrients. However, this tofu by-product is sparingly exploited and is used as animal feed, fertilized or discarded as effluent [Matemu et al., 2009].

Proteins are one of the major and useful components of soy-whey and tofu-whey. Although the thermal behavior of dried soy-whey, dried tofu-whey and their isolated proteins was fairly studied by differential scanning calorimetry in previous papers [Sobral \& Wagner, 2007; Sobral et al., 2010], the studies concerning the emulsifying properties of the mentioned samples are still relatively scarce [Kasran et al., 2013, Matemu et al., 2009; Palazolo et al., 2004; Ray \& Rousseau, 2013]. In addition, in a previous work, Palazolo et al. [2013] found that dehydrated tofu-whey improved the freeze-thaw stability of protein-stabilized $\mathrm{o} / \mathrm{w}$ emulsions after prolonged freezing times. However, in that study, this sample was not directly used as an emulsifier.

The aim of this study was to evaluate the emulsifying properties of dried soy-whey and dried tofu-whey and their isolated proteins. Dehydration was performed by lyophilization or thermal drying and the isolation of proteins was carried out by employing the classical method of precipitation with organic solvent. It is worth noting that the model emulsions were prepared using a high-speed blender to highlight the differences between samples. Then, the emulsion stability under quiescent storage was also evaluated.

\section{MATERIALS AND METHODS}

\section{Materials}

Defatted soy flour, provided by Solae Latin America (Barueri; São Paulo, Brazil), contains 5.0 g/100 g moisture and its composition $(\mathrm{g} / 100 \mathrm{~g}$ in dry basis, as given by the producer) is: crude protein $(\mathrm{N} \times 6.25), 56.0$, ash, 7.0, total lipids, 3.5 , insoluble dietary fiber 12.7 and soluble dietary fiber, 1.3. The tofu-whey (pH 5.5 \pm 0.5$)$ was donated by Soyana S.H. (General San Martín, Buenos Aires, Argentina). The chemi- cal composition of tofu-whey (g/100 g) was: crude protein $(\mathrm{N} \times 6.25), 4.62 \pm 0.14$, total carbohydrates, 8.77 \pm 0.38 , ash (dry ashing at $550 \pm 5^{\circ} \mathrm{C}$ ), $5.14 \pm 0.01$ and lipids $0.024 \pm 0.001$. Acetone (HPLC grade) was purchased from J. T. Baker (Avantor Performance Materials, LLC, PA, USA). Crystalline porcine trypsin (Type IX), bovine serum albumin (fatty acid free) and anhydrous glucose were purchased from Sigma-Aldrich Co. (St. Louis, MO, USA). Sudan III (Solvent Red 23, CI number 26,100) was bought from Chroma Gesselschaft (Schmidt GmbH \& Co.; Stuttgart-Untertükheim, Germany). Distilled water was always used in all assays and all the other chemicals were analytical grade reagents purchased from Anedra (Research AG; Talar, Buenos Aires, Argentina).

\section{Preparation of soy-whey}

Defatted soy flour was dispersed by magnetic stirring in distilled water $(100.0 \mathrm{~g}$ flour/L) and the $\mathrm{pH}$ was adjusted to 8.0 with $2.0 \mathrm{~mol} / \mathrm{L} \mathrm{NaOH}$ solution. The stirring was performed for $2 \mathrm{~h}$ at $25^{\circ} \mathrm{C}$ to ensure the total dispersion and hydration. Then, the aqueous dispersion was centrifuged $\left(10,400 \times \mathrm{g}, 15 \mathrm{~min}, 20^{\circ} \mathrm{C}\right.$, Beckman Coulter Avanti J25 centrifuge, JA14 rotor, Beckman Coulter Inc.; Fullerton, USA); the pellet was discarded and the supernatant was adjusted to $\mathrm{pH} 4.5$ with $1.0 \mathrm{~mol} / \mathrm{L} \mathrm{HCl}$ solution to precipitate the storage soy proteins. Soy-whey was separated from acid aqueous dispersion by centrifugation in the conditions mentioned above [Sobral et al., 2010]. Soy-whey was stored at $4^{\circ} \mathrm{C}$ before its processing and sodium azide was added $(0.03 \mathrm{~g} / 100 \mathrm{~mL})$ to avoid the microbial spoilage. The chemical composition of soy-whey $(\mathrm{g} / 100 \mathrm{~g})$ was: crude protein $(\mathrm{N} \times 6.25)$, $5.34 \pm 0.08$, total carbohydrates, $17.27 \pm 0.43$ and ash (dry ashing at $\left.550 \pm 5^{\circ} \mathrm{C}\right), 4.39 \pm 0.03$. For this liquid sample, lipid content was negligible.

\section{Preparation of dried soy-whey and dried tofu-whey samples}

Soy-whey and tofu-whey (both without previous $\mathrm{pH}$ adjustment) were dried by following two different processes: freeze-drying and thermal drying. A part of these samples were directly lyophilized $\left(-50^{\circ} \mathrm{C}, 0.002 \mathrm{kPa}\right.$, Heto FD4 freeze-dryer; Denmark), resulting in the samples LSW and LTW. The other parts were processed according to experimental procedure reported by Palazolo et al. [2013]. Firstly, whey was concentrated $\left(50^{\circ} \mathrm{C}, 60 \mathrm{~mm} \mathrm{Hg}, 8.0 \mathrm{kPa}\right)$ using a rotavapor (R-124, Büchi Labortechnik AG; Postfach, Switzerland) and the obtained syrup was dried at $50^{\circ} \mathrm{C}$ and $10 \mathrm{~mm} \mathrm{Hg}$ $(1.33 \mathrm{kPa})$ for $4 \mathrm{~h}$ (Gallenkamp vacuum oven, Weiss Technik UK; Leicestershire, UK). Samples obtained as sticky scales were treated with liquid nitrogen, ground and dried consecutively in desiccators containing silica gel, $\mathrm{CaO}$ and finally, $\mathrm{P}_{2} \mathrm{O}_{5}$. Fine powders corresponding to the thermal dehydrated soy-whey (DSW) and dehydrated tofu-whey (DTW) were finally obtained.

Additionally, in order to inactivate the Kunitz trypsin inhibitor, the LSW sample was thermally treated up to $150^{\circ} \mathrm{C}$ [Sobral \& Wagner, 2007], obtaining the h-LSW sample. For this purpose, LSW sample $(200 \pm 50 \mathrm{mg})$ was put in a reusable stainless steel cell with screw lid. The sample was carefully sealed within the cell to remove the trapped air. LSW 
sample was heated for $25 \mathrm{~min}$ from 25 to $150^{\circ} \mathrm{C}$, at $5^{\circ} \mathrm{C} \cdot \mathrm{min}^{-1}$ (INDEF electric oven; Córdoba, Argentina) and further cooled to room temperature.

As a consequence of their high tendency to hydration, all dried samples were kept in anhydrous conditions before both their characterization assays and the preparation of emulsions.

\section{Preparation of isolated proteins from lyophilized soy- -whey and lyophilized tofu-whey}

LSW, h-LSW and LTW samples were dispersed in distilled water $(5.0 \mathrm{~g} / 100 \mathrm{~mL})$ by magnetic stirring for at least $2 \mathrm{~h}$ to ensure total dispersion and hydration. Isolated proteins were obtained from these dispersions by precipitation with cold acetone. The organic solvent, previously cooled at $-20^{\circ} \mathrm{C}$, was progressively added to whey samples (whey/acetone volume ratio $1: 1)$. The temperature was maintained at $0^{\circ} \mathrm{C}$ during the precipitation step [Sobral et al., 2010]. The precipitated proteins were separated by centrifugation $(10,400 \times \mathrm{g}, 20 \mathrm{~min}$, $20^{\circ} \mathrm{C}$, Beckman Coulter Avanti J25 centrifuge, JA14 rotor, Beckman Coulter Inc.; Fullerton, USA), dispersed in distilled water and finally lyophilized $\left(-50{ }^{\circ} \mathrm{C}, 0.002 \mathrm{kPa}\right.$, Heto FD4 freeze-dryer; Denmark), which resulted in the samples LSW-P, h-LSW-P and LTW-P, respectively.

\section{Characterization assays on samples}

\section{Chemical composition}

Crude protein content was determined by Kjeldahl method $(\mathrm{N} \times 6.25)$ (AOAC 920.87 method) [AOAC, 1997]. Total carbohydrate content was determined by the phenol-sulfuric acid method (AOAC 988.12 method), using phenol solution $(0.5 \mathrm{~g} / \mathrm{L})$ as phenolic compound and D-glucose as standard sugar [AOAC, 1997]. Ash determination was carried out by dry-ashing at $55 \pm 05^{\circ} \mathrm{C}$ [Marshall, 2009]. To determine calcium content, ash was dissolved in $0.14 \mathrm{~mol} / \mathrm{L}$ nitric acid and $0.05 \mathrm{~g} / \mathrm{L}$ lanthanum and filtered through a membrane $(0.45 \mu \mathrm{m}$ pore size). Calcium content was determined by atomic absorption spectroscopy using a Shimadzu AA6650 spectrophotometer (Shimadzu Corporation; Duisburg, Germany) at $422.7 \mathrm{~nm}$ [Sobral et al., 2010]. All parameters were expressed in grams per $100 \mathrm{~g}$.

Determination of protein solubility and carbohydrates/TCA protein mass ratio

Samples were dispersed in $10 \mathrm{mmol} / \mathrm{L}$ sodium phosphate buffer, pH $7.0(0.1 \mathrm{~g}$ sample/L) under gentle magnetic stirring for $2 \mathrm{~h}$ at $25^{\circ} \mathrm{C}$. They were then centrifuged at $9,300 \times \mathrm{g}$ (Beckman Coulter Avanti J25 centrifuge, JA14 rotor, Beckman Coulter Inc.; Fullerton, USA) for $20 \mathrm{~min}$ at $20^{\circ} \mathrm{C}$, and protein concentration in the supernatant was determined after interfering substances elimination, mainly free sugars. To eliminate interferences, proteins were precipitated by adding $120.0 \mathrm{~g} / \mathrm{L}$ trichloroacetic acid (TCA) solution. Then, they were recovered by centrifugation $\left(9,300 \times \mathrm{g}, 20^{\circ} \mathrm{C}, 20 \mathrm{~min}\right)$, washed two times with TCA solution and finally, solubilized with $0.1 \mathrm{~mol} / \mathrm{L} \mathrm{NaOH}$ reaching the same starting volume. In this solution, protein content $\left(\mathrm{P}_{\mathrm{S}-\mathrm{TCA}}\right)$ was determined by the enhanced alkaline copper protein assay, using serum bovine albumin as a standard protein [Stoscheck, 1990]. The same experimental procedure was applied for aqueous dispersions without previous centrifugation, to obtain the total protein content $\left(\mathrm{P}_{\mathrm{T}-\mathrm{TCA}}\right)$. Protein solubility (expressed as $\mathrm{g}$ soluble protein per $100 \mathrm{~g}$ total protein) was calculated as:

Protein solubility $=\left(\mathrm{P}_{\mathrm{S}-\mathrm{TCA}} / \mathrm{P}_{\mathrm{T}-\mathrm{TCA}}\right) \times 100$

In addition, to estimate the amount of carbohydrates linked to proteins, in the same protein solutions obtained after the TCA treatment and alkaline solubilization, the carbohydrate content $(\mathrm{CH})$ was determined by the phenol-sulfuric acid method (AOAC method 988.12) [AOAC, 1997]. Then, the carbohydrates/protein mass ratio ( $\mathrm{mg} \mathrm{CH} / \mathrm{mg}$ protein) was calculated to both solutions $\left(\mathrm{CH} / \mathrm{P}_{\mathrm{T}-\mathrm{TCA}}\right.$ and $\mathrm{CH} / \mathrm{P}_{\mathrm{S}-\mathrm{TCA}}$, respectively).

\section{Protein denaturation degree}

Sample dispersions (30.0 g/100 g in distilled water) were hermetically sealed in standard aluminum pans. Thermograms were obtained at a $10^{\circ} \mathrm{C} / \mathrm{min}$ heating rate in a range of $20-120^{\circ} \mathrm{C}$ using a differential scanning calorimeter Q-200 (TA Instruments, LCC Waters; New Castle, DE, USA). An empty pan was used as reference. Areas below the endothermic curves were measured to calculate the corresponding total thermal denaturation enthalpy $\left(\Delta \mathrm{H}_{\mathrm{d}}, \mathrm{J} / \mathrm{g}\right.$ protein $)$. For whey samples, the protein denaturation degree was calculated as: $\left(\Delta \mathrm{H}_{\mathrm{d}} / 11.76\right) \times 100$, where 11.76 is the denaturation enthalpy value $(\mathrm{J} / \mathrm{g}$ protein) for lyophilized fresh soy whey, LSW. Moreover, the protein denaturation degree for isolated proteins was calculated as: $\left(\Delta \mathrm{H}_{\mathrm{d}} / 10.8\right) \times 100$, where 10.8 is the denaturation enthalpy value ( $\mathrm{J} / \mathrm{g}$ protein) for whey soy proteins precipitated with ammonium sulfate from fresh soy-whey [Sobral \& Wagner, 2007].

\section{Trypsin inhibitor activity}

Trypsin inhibitor activity (TIA) was determined using the method reported by Sobral \& Wagner [2007]. In this assay, the decrease of porcine trypsin activity on denatured hemoglobin solution was evaluated by addition of aqueous dispersions of different samples. The relative TIA (r-TIA) was calculated taking the TIA value of fresh soy-whey sample as $100 \%$.

\section{Preparation of $\mathrm{o} / \mathrm{w}$ emulsions}

Aqueous dispersions were prepared by dispersing the solid samples in $10 \mathrm{mM}$ sodium phosphate buffer, $\mathrm{pH} 7.0$ by magnetic stirring for at least $2 \mathrm{~h}$ to ensure total dispersion and hydration. According to chemical composition (Table 1), all samples were dispersed at equivalent crude protein concentration $(0.1,0.5$ and $1.0 \mathrm{~g} / 100 \mathrm{~mL})$. To obtain $\mathrm{o} / \mathrm{w}$ emulsions, $10 \mathrm{~g}$ of aqueous dispersions and $5 \mathrm{~g}$ of refined sunflower oil (oil mass fraction $=0.33$ ) were mixed by using a high-speed rotor/stator device (Ultraturrax T-25, S25-N8G dispersing tool, IKA Labortechnik; Staufen, Germany) at 20,000 rpm for $1 \mathrm{~min}$. The fresh emulsions were immediately used for characterization assays. 


\section{Characterization assays of $\mathrm{o} / \mathrm{w}$ emulsions}

\section{Particle size distribution}

Particle size distribution of fresh emulsions was determined as differential volume in the diameter range 0.1 $1000 \mu \mathrm{m}$ by laser diffraction (Malvern Mastersizer 2000E particle analyzer, Malvern Instruments Ltd; Worcestershire, UK). Two aliquots of each emulsion were separately diluted with $10 \mathrm{mM}$ sodium phosphate buffer without and with $10.0 \mathrm{~g} / \mathrm{L}$ sodium dodecyl sulfate (SDS). To avoid multiple scattering effects, the samples prepared in the absence and presence of the surfactant were dispersed in $600 \mathrm{~mL}$ of water at 2,000 rpm (Hydro 2000MU wet dispersion unit, Malvern Instruments Ltd; Worcestershire, UK). The optical parameters were: refractive index for oil and water, 1.47 and 1.33 respectively; adsorption coefficient, 0.001 . From the particle size distribution, the De Brouckere, weighted-volume diameter $\left(\mathrm{D}_{4,3}\right)$ was obtained and flocculation index was calculated as:

Flocculation index $=\left[\left(\mathrm{D}_{4,3+\mathrm{SDS}}-\mathrm{D}_{4,3-\mathrm{SDS}}\right) / \mathrm{D}_{4,3+\mathrm{SDS}}\right] \times 100$

where: $\mathrm{D}_{4,3-\mathrm{SDS}}$ and $\mathrm{D}_{4,3+\mathrm{SDS}}$ were the volume-weighted diameters obtained from the particle size distribution determined in the absence and presence of SDS, respectively [Palazolo et al., 2013]. $\mathrm{D}_{4,3}$ mean diameters were selected due to they are more sensitive to the presence of large particles in the emulsion [McClements, 2007]. In measuring without SDS, dilution and stirring were likely to disrupt any weakly flocculated droplets, but leave strongly flocculated droplets intact; therefore this method allows evaluating flocs stable in the measurement conditions [Thanasukarn et al., 2004].

\section{Emulsion stability in quiescent conditions}

The emulsion stability was analyzed without previous dilution using a vertical scan analyzer (Quick Scan, Beckman Coulter; Fullerton, CA, USA), according to the multiple light scattering theory [Mengual et al., 1999]. Immediately after their preparation, emulsions were put in a cylindrical glass measurement tube until the sample height was $65 \mathrm{~mm}$; then, the backscattering (BS) profiles were registered at $25^{\circ} \mathrm{C}$ as a function of the sample height. Measurements were performed at 1-min intervals for $60 \mathrm{~min}$ and finally, some measurements were carried out after $24 \mathrm{~h}$ of quiescent storage, at different time intervals.

To evaluate the emulsion destabilization, creaming-flocculation kinetics was followed by measuring the mean values of $\mathrm{BS}$ as a function of time in a lower part of tube $\left(\mathrm{BS}_{\text {bottom }}\right.$ zone 15-17 mm) [Palazolo et al., 2004]. The gravitational separation kinetic constant $(\mathrm{K})$ was calculated as:

$\mathrm{K}\left(\mathrm{min}^{-1}\right)=\left(\mathrm{BS}_{0}, \text { bottom } \times \mathrm{t}_{0.5}\right)^{-1}$

where: $\mathrm{BS}_{0 \text {, bottom }}$ is the initial value of $\mathrm{BS}_{\text {bottom }}(\mathrm{t}=0)$ and $\mathrm{t}_{0.5}$ is the time ( $\mathrm{min}$ ) where $\mathrm{BS}_{\text {bottom }}=0.5 \times \mathrm{BS}_{0 \text {, bottom }}$. At the same time, the kinetics of formation and destabilization of cream layer was followed through the variation of mean values of BS in the upper part of tube ( $\mathrm{BS}_{\text {top }}$, zone 60-62 mm). The cross section of the measurement glass tube is uniform.
Therefore, the relative cream layer volume ( $\mathrm{Vr}$ ) was determined after $24 \mathrm{~h}$ of quiescent storage as:

$\mathrm{V}_{\mathrm{r}}=\left(\mathrm{L}_{\mathrm{c}} / \mathrm{L}_{\mathrm{e}}\right) \times 100$

where: $\mathrm{L}_{c}$ is the length of cream layer and $\mathrm{L}_{\mathrm{e}}$ is the length of entire emulsion (cream phase + serum phase, $65 \mathrm{~mm}$ ) [Palazolo et al., 2004]. Both parameters $\left(\mathrm{L}_{\mathrm{c}}, \mathrm{L}_{\mathrm{e}}\right)$ were obtained from $24 \mathrm{~h}$ BS profile, using the software associated to analyzer (QUICKScan, version 1.2.2, Formulaction; France, 1998).

\section{Determination of oiling off}

The dye-dilution technique was utilized to determine the amount of free oil of $\mathrm{o} / \mathrm{w}$ emulsions after $24 \mathrm{~h}$ of quiescent storage. The experimental procedure of Palanuwech et al. [2003] was followed with some modifications [Palazolo et al., 2013]. Sudan III solution $\left(1.5 \times 10^{-4} \mathrm{~g} / \mathrm{kg}\right.$ in sunflower oil) was gently mixed with emulsions, incubated for $60 \mathrm{~min}$ at room temperature and then centrifuged at $700 \times \mathrm{g}$ for $20 \mathrm{~min}$ (Rolco CM 4080 Millenium centrifuge; Buenos Aires, Argentina). An aliquot of dyed free oil on top of emulsion was carefully sucked off with a Pasteur pipette and centrifuged at $10,000 \times \mathrm{g}$ for $20 \mathrm{~min}$ (Beckman Coulter GS-15R centrifuge, Beckman Coulter Inc., USA). The absorbance of supernatant at $508 \mathrm{~nm}$ was then read (T60 UV visible spectrophotometer, PG Instruments, Leicestershire, United Kingdom). The change in the absorbance due to dye dilution was related to the content of free oil, according to the expression:

Free oil $(\mathrm{g} / 100 \mathrm{~g}$ total oil $)=\left[\mathrm{M}_{\mathrm{o}} \times(\mathrm{A}-1) /\left(\mathrm{M}_{\mathrm{e}} \times \Phi_{\mathrm{e}}\right)\right] \times 100(5)$

where: $M_{0}$ is the mass ( $g$ ) of added dye solution, $M_{e}$ is the mass (g) of emulsion, $\Phi_{\mathrm{e}}$ is the mass fraction of oil in the emulsion and $\mathrm{A}$ is the ratio of the measured absorbances of the dye before $\left(A_{b}\right)$ and after $\left(A_{a}\right)$ extraction process. The corresponding procedures of calibration for free oil content determination were carried out according to original work [Palanuwech et al., 2003].

\section{Statistical analysis}

All assays were measured at least in triplicate $(n=3)$ and the results were reported as the mean and standard deviation. Data were analyzed by analysis of variance (ANOVA) and differences between mean values were determined by the Fisher's Least Significant Differences (LSD) at $\mathrm{p}<0.05$ significance level. Statistical analysis was carried out using Statgraphics Centurion XV software (Statpoint Technologies Inc.; Warrenton, VA, USA).

\section{RESULTS AND DISCUSSION}

\section{Physicochemical characterization of dried whey samples}

Firstly, the physicochemical characterization of dried whey samples was assessed. The results are shown in Table 1. The total carbohydrate content was similar for all whey samples $(p>0.05)$. The samples obtained from drying of tofu-whey (DTW, LTW) evidenced significantly higher ash and calcium contents than those of all other samples (LSW, h-LSW and DSW) $(\mathrm{p}<0.05)$. This result would be attributed 
TABLE 1. Chemical composition, protein solubility, protein denaturation degree and relative trypsin inhibitor activity (r-TIA) for dried samples obtained from soy-whey and tofu-whey. Carbohydrate/protein mass ratio was obtained for the total fraction $\left(\mathrm{CH} / \mathrm{P}_{\mathrm{T}-\mathrm{TCA}}\right)$ and soluble fraction $\left(\mathrm{CH}-\mathrm{P}_{\mathrm{S}-\mathrm{TCA}}\right)$ (see Materials and Methods section).

\begin{tabular}{|c|c|c|c|c|c|c|c|c|c|}
\hline \multirow{3}{*}{ Sample } & \multicolumn{6}{|c|}{ Chemical composition } & \multirow{3}{*}{$\begin{array}{c}\text { Protein } \\
\text { solubility } \\
\text { (g/100 g total } \\
\text { protein) }\end{array}$} & \multirow{3}{*}{$\begin{array}{l}\text { Protein } \\
\text { denaturation } \\
\text { degree } \\
(\%)\end{array}$} & \multirow{3}{*}{$\begin{array}{c}\text { r-TIA } \\
(\%)\end{array}$} \\
\hline & \multirow{2}{*}{$\begin{array}{c}\text { Crude protein } \\
(\mathrm{N} \times 6.25) \\
(\mathrm{g} / 100 \mathrm{~g})\end{array}$} & \multirow{2}{*}{$\begin{array}{l}\text { Total } \\
\text { carbohydrates } \\
(\mathrm{g} / 100 \mathrm{~g})\end{array}$} & \multirow[t]{2}{*}{$\begin{array}{c}\text { Ash } \\
(\mathrm{g} / 100 \mathrm{~g})\end{array}$} & \multirow[t]{2}{*}{$\begin{array}{l}\text { Calcium } \\
(\mathrm{g} / 100 \mathrm{~g})\end{array}$} & \multicolumn{2}{|c|}{$\begin{array}{c}\text { Carbohydrates/ } \\
\text { protein mass ratio } \\
\text { (mg CH/100 mg protein) }\end{array}$} & & & \\
\hline & & & & & $\mathrm{CH} / \mathrm{P}_{\mathrm{T}-\mathrm{TCA}}$ & $\mathrm{CH} / \mathrm{P}_{\mathrm{S}, \mathrm{TCA}}$ & & & \\
\hline DSW & $16.4 \pm 0.1^{\mathrm{a}}$ & $69.2 \pm 2.3^{\mathrm{a}}$ & $14.1 \pm 0.2^{b}$ & $0.31 \pm 0.07^{b}$ & $11.2 \pm 0.8^{\mathrm{b}, \mathrm{A}}$ & $12.2 \pm 0.3^{\mathrm{b}, \mathrm{A}}$ & $64.2 \pm 0.5^{\mathrm{d}}$ & $70 \pm 2^{b}$ & $2.5 \pm 0.2^{\mathrm{d}}$ \\
\hline LSW & $16.3 \pm 0.1^{\mathrm{a}}$ & $68.0 \pm 2.7^{\mathrm{a}}$ & $13.8 \pm 0.3^{\mathrm{b}}$ & $0.25 \pm 0.06^{b}$ & $3.1 \pm 0.3^{\mathrm{d}, \mathrm{A}}$ & $3.9 \pm 1.0^{\mathrm{d}, \mathrm{A}}$ & $84.5 \pm 0.5^{\mathrm{a}}$ & $0.0^{\mathrm{b}}$ & $94.5 \pm 4.0^{\mathrm{a}}$ \\
\hline h-LSW & $16.3 \pm 0.1^{\mathrm{a}}$ & $69.1 \pm 1.7^{\mathrm{a}}$ & $14.1 \pm 0.2^{\mathrm{b}}$ & $0.31 \pm 0.07^{b}$ & $20.1 \pm 1.1^{\mathrm{a}, \mathrm{B}}$ & $34.3 \pm 0.7^{\mathrm{a}, \mathrm{A}}$ & $59.5 \pm 0.6^{c}$ & $100^{a}$ & $4.6 \pm 0.3^{\mathrm{c}}$ \\
\hline DTW & $15.5 \pm 0.1^{\mathrm{b}}$ & $67.6 \pm 2.1^{\mathrm{a}}$ & $16.4 \pm 0.2^{\mathrm{a}}$ & $3.25 \pm 0.16^{\mathrm{a}}$ & $9.2 \pm 0.8^{\mathrm{c}, \mathrm{A}}$ & $10.0 \pm 1.2^{\mathrm{c}, \mathrm{A}}$ & $80.3 \pm 1.7^{\mathrm{b}}$ & $100^{\mathrm{a}}$ & $<0.2$ \\
\hline LTW & $15.3 \pm 0.2^{b}$ & $67.2 \pm 1.2^{\mathrm{a}}$ & $16.7 \pm 0.1^{\mathrm{a}}$ & $3.39 \pm 0.01^{\mathrm{a}}$ & $9.0 \pm 0.6^{\mathrm{c}, \mathrm{B}}$ & $11.5 \pm 0.3^{\mathrm{c}, \mathrm{A}}$ & $85.1 \pm 0.7^{\mathrm{a}}$ & $100^{\mathrm{a}}$ & $28.6 \pm 2.7^{b}$ \\
\hline
\end{tabular}

Mean values $(n=3)$ followed by different lowercase letters within the same column indicate significant differences as determined by Fisher's test $(\mathrm{p}<0.05)$.

For carbohydrates/protein mass ratio, mean values $(n=3)$ followed by different uppercase letters within the same row indicate significant differences as determined by Fisher's test $(\mathrm{p}<0.05)$.

to the presence of calcium ion, which remains in this sample after the almost total precipitation of storage soy proteins (glycinin, $\beta$-conglycinin) after heating and addition of calcium salts during the preparation of tofu from soymilk [Meng et al., 2016]. Besides, all samples showed a similar content of crude protein $(\sim 15-16 \mathrm{~g} / 100 \mathrm{~g})$ although they were slightly lower for those prepared from tofu-whey $(\mathrm{p}<0.05)$. According to previous works [Ray \& Rousseau, 2013], the protein fraction of soy-whey is mainly constituted by Kunitz trypsin inhibitor (KTI) and lectin whereas tofu-whey also evidenced the presence of some subunits of soy storage globulins, which remain soluble after thermal treatment of soymilk in the presence of calcium salts. According to Kao et al. [2003], although tofuwhey proteins are mainly constituted by low molecular weight proteins $(<16 \mathrm{kDa})$, as corroborated by tricine-SDS-PAGE, the presence of subunits of soy storage globulins is highly dependent of the concentration of added calcium salts. The industrial heating stage performed during the obtaining of tofu, also induced the total denaturation of KTI and lectin; for LTW sample this fact was evidenced by the absence of DSC endothermic transitions in the range of $20-120^{\circ} \mathrm{C}$. However, its r-TIA $(\sim 29 \%)$ could be attributed to the presence of Bowman-Birk trypsin inhibitor (BBTI). It is well known that BBTI exhibits more resistance against heating than KTI owing to its different molecular compositions and conformations [Huang et al., 2008; Chen et al., 2014]. In addition, LSW sample exhibited the highest value of r-TIA, indicating that freeze-drying had little influence on the activity of trypsin inhibitors. This result was consistent with the presence of native KTI and lectin, with a negligible protein denaturation degree $(\sim 0)$. Conversely, whey samples obtained by thermal drying evidenced residual values of r-TIA. For DTW sample, no endothermic transitions were observed by DSC, according to characteristics of raw material. As was mentioned above, soy-whey is constituted by native trypsin inhibitors and lectin. Nevertheless, after thermal drying, an important degree of protein denaturation was reached for DSW sample $(\sim 70 \%)$, in clear agreement with its residual r-TIA (Table 1).
Protein solubility assays were also carried out to evaluate the protein aggregation status of all samples. Broadly, protein solubility was significantly higher for whey samples obtained by freeze-drying whatever the raw material. The protein aggregation induced by thermal drying was more evident for the samples obtained from soy-whey: for DSW sample, the protein solubility was almost $20 \%$ lower than that of LSW (Table 1). In addition, h-LSW sample was prepared by heating $\mathrm{LSW}$ sample from $25^{\circ} \mathrm{C}$ to $150^{\circ} \mathrm{C}$ in anhydrous conditions. The thermal treatment performed on lyophilized whey sample, induced a total protein denaturation and a significant decrease of r-TIA, in accordance with the results previously reported by Sobral \& Wagner [2007]. These authors observed that the heating of lyophilized soy-whey samples above $100^{\circ} \mathrm{C}$ produced both the denaturation of KTI and lectin and protein glycosylation with soy-whey carbohydrates, leading to formation of protein aggregates evidenced by SDS-PAGE. Moreover, according to Sobral \& Wagner [2007], the protein denaturation degree of both soy-whey proteins noticeably increased when heating temperature was raised from 100 to $150^{\circ} \mathrm{C}$. In this paper, a decrease of protein solubility of h-LSW respect to that of LSW was effectively observed $(p<0.05)$. Although the loss of reactive or available lysine was not determined in this work, the decrease of protein solubility was in clear concordance with a higher amount of protein linked to carbohydrates, which simultaneously precipitated with TCA addition. This phenomenon was consistent with an increase of $\mathrm{CH} / \mathrm{P}_{\mathrm{T}-\mathrm{TCA}}$, and $\mathrm{CH} / \mathrm{P}_{\mathrm{S}-\mathrm{TCA}}$ parameters for h-LSW sample, which were almost 7 and 9 times higher than those of LSW (Table 1). Based on these results, although the loss of protein solubility could be attributed to protein aggregation mediated by interaction between protein molecules, the complexation between carbohydrates and proteins also occurs probably as a result of glycosylation.

\section{Emulsifying properties of dried whey samples}

In this section, the emulsifying properties of dried whey samples were assessed. All emulsions were prepared at equiv- 
alent crude protein concentration $(0.1,0.5$ and $1.0 \mathrm{~g} / 100 \mathrm{~mL})$ in the continuous phase. In this condition, the salt content of emulsions prepared with DTW and LTW samples was significantly higher than those of all other samples, due to high mineral and calcium content of tofu-whey. Firstly, the creaming-flocculation stability in quiescent conditions was evaluated. The results, after the first $10 \mathrm{~min}$ of quiescent storage, are shown in Figure 1 A-C. At $0.1 \mathrm{~g} / 100 \mathrm{~mL}$, all emulsions were destabilized. Nevertheless, LTW emulsions showed the highest stability. For the highly unstable DSW and LSW emulsions, the initial $\mathrm{BS}_{\text {bottom }}\left(\mathrm{BS}_{0 \text {, bottom }}\right)$ was fairly lower than for all other emulsions. At $\mathrm{t}=0 \mathrm{~min}$, the droplet concentration is uniform throughout the measurement cell. Thus, the low $\mathrm{BS}_{0 \text {, bottom }}$ values would be indicative of the presence of greater individual droplets or flocs [Palazolo et al., 2004]. With the exception of DSW emulsions, the stability to creamingflocculation increased with increasing protein concentration $(0.5$ and $1.0 \mathrm{~g} / 100 \mathrm{~mL})$. For LTW emulsions, no $\mathrm{BS}_{\text {bottom }}$ decrease was evidenced after 10 min of storage. At higher protein concentrations ( 0.5 and $1.0 \mathrm{~g} / 100 \mathrm{~mL}$ ), emulsion stability decreased in the order: $\mathrm{LTW}>\mathrm{DTW}>\mathrm{h}-\mathrm{LSW}>\mathrm{LSW}>\mathrm{DSW}$.
In addition, $\mathrm{BS}_{0 \text {, bottom }}$ and $\mathrm{K}$ parameters are summarized in Table 2. It can be observed that $\mathrm{BS}_{0 \text {, bottom }}$ increased with increasing protein concentration in the continuous phase, which is consistent with the presence of particles of lower size [Palazolo et al., 2004]. Although interfacial protein load parameter was not measured in this paper, it is highly probable that emulsifier concentration is limiting, especially at the lowest protein concentration $(0.1 \mathrm{~g} / 100 \mathrm{~mL})$. Under this condition, the droplet size is governed primarily by the emulsifier concentration, rather than by the energy input of the homogenizer. Indeed, re-coalescence during homogenization would be more important at low protein concentration where there will be gaps in the interfacial membranes surroundings the droplets when new surfaces are continuously being created by the intense forces generated within a homogenizer [McClements, 2004; Jafari et al., 2008]. In addition, an increase of $\mathrm{K}$ was attributed to a higher rate of upward movement of droplets. In clear concordance with the $\mathrm{BS}_{\text {bottom }}$ profiles, $\mathrm{K}$ decreased with increasing protein concentration for all emulsions. LTW emulsions exhibited the highest stability to gravitational separation at all protein concentrations (Table 2).
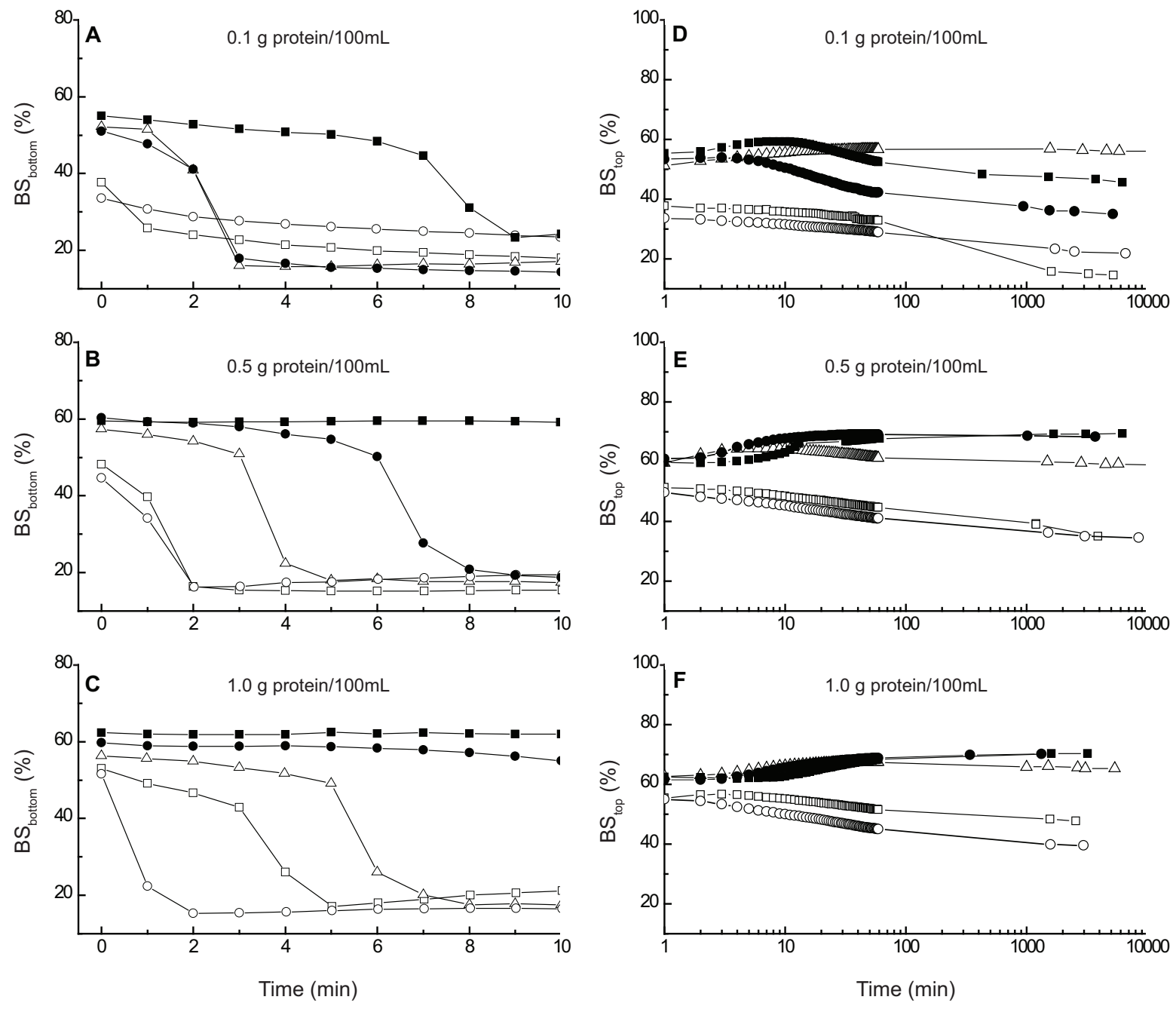

$$
- \text { O-DSW } \square-\text { LSW } \triangle \text { h-LSW } \multimap \text { DTW } \square-\text { LTW }
$$

FIGURE 1. Creaming-flocculation kinetic ( $\mathrm{BS}_{\mathrm{bottom}}$, zone $15-17 \mathrm{~mm}$, as a function of time) for o/w emulsions prepared with different dried whey samples at equivalent protein concentration $(\mathrm{A}, \mathrm{B}, \mathrm{C})$. Kinetic of formation and destabilization of cream layer (BS top $_{\text {, }}$ zone $60-62 \mathrm{~mm}$, as a function of time) for $\mathrm{o} / \mathrm{w}$ emulsions prepared with different dried whey samples at equivalent protein concentration (D,E,F). 
TABLE 2. Initial mean $(\mathrm{t}=0)$ values of backscattering $\left(\mathrm{BS}_{0, \mathrm{totom}}\right.$, zone 15-17 mm), gravitational separation kinetic constant $(\mathrm{K})$ and relative cream layer volume $(\mathrm{Vr})$ for $\mathrm{o} / \mathrm{w}$ emulsions prepared with different dried whey samples at equivalent protein concentration in the continuous phase.

\begin{tabular}{l|c|c|c|c}
\hline Sample & $\begin{array}{c}\text { Protein } \\
(\mathrm{g} / 100 \mathrm{~mL})\end{array}$ & $\begin{array}{c}\mathrm{BS}_{0 \text { bottom }} \\
(\%)\end{array}$ & $\begin{array}{c}\mathrm{K} \\
\left(\mathrm{min}^{-1}\right)\end{array}$ & $\begin{array}{c}\mathrm{Vr} \\
(\%)\end{array}$ \\
\hline DSW & & $31.3 \pm 4.1^{\mathrm{g}}$ & $30.6 \pm 0.1^{\mathrm{a}}$ & $30.9 \pm 1.8^{\mathrm{g}}$ \\
LSW & & $37.7 \pm 1.7^{\mathrm{f}}$ & $13.3 \pm 0.7^{\mathrm{c}}$ & $35.0 \pm 3.3^{\mathrm{f}}$ \\
h-LSW & 0.1 & $50.5 \pm 2.3^{\mathrm{d}}$ & $6.4 \pm 1.3^{\mathrm{d}}$ & $54.4 \pm 0.5^{\mathrm{c}}$ \\
DTW & & $51.0 \pm 2.3^{\mathrm{d}}$ & $7.3 \pm 1.5^{\mathrm{d}}$ & $40.5 \pm 4.4^{\mathrm{f}}$ \\
LTW & & $55.1 \pm 2.5^{\mathrm{c}, \mathrm{d}}$ & $2.1 \pm 0.4^{\mathrm{f}}$ & $54.6 \pm 0.5^{\mathrm{c}}$ \\
\hline DSW & & $44.4 \pm 0.3^{\mathrm{f}}$ & $25.7 \pm 2.2^{\mathrm{b}}$ & $44.2 \pm 1.9^{\mathrm{e}}$ \\
LSW & & $48.2 \pm 0.6^{\mathrm{e}}$ & $12.4 \pm 1.0^{\mathrm{c}}$ & $45.7 \pm 2.0^{\mathrm{e}}$ \\
h-LSW & 0.5 & $56.8 \pm 0.7^{\mathrm{c}}$ & $4.4 \pm 0.3^{\mathrm{e}}$ & $54.6 \pm 2.0^{\mathrm{c}}$ \\
DTW & & $59.2 \pm 0.7^{\mathrm{b}}$ & $2.4 \pm 0.2^{\mathrm{f}}$ & $48.9 \pm 2.1^{\mathrm{d}}$ \\
LTW & & $59.5 \pm 0.8^{\mathrm{b}}$ & $1.6 \pm 0.1^{\mathrm{f}}$ & $55.1 \pm 2.4^{\mathrm{c}}$ \\
\hline DSW & & $49.0 \pm 4.0^{\mathrm{d}, \mathrm{e}}$ & $21.8 \pm 4.0^{\mathrm{b}}$ & $46.9 \pm 0.4^{\mathrm{e}}$ \\
LSW & & $53.0 \pm 0.6^{\mathrm{d}}$ & $4.7 \pm 0.4^{\mathrm{e}}$ & $46.0 \pm 0.4^{\mathrm{e}}$ \\
h-LSW & 1.0 & $56.3 \pm 0.7^{\mathrm{c}}$ & $3.1 \pm 0.2^{\mathrm{f}}$ & $56.3 \pm 2.5^{\mathrm{b}}$ \\
DTW & & $60.3 \pm 0.8^{\mathrm{a}, \mathrm{b}}$ & $1.1 \pm 0.1^{\mathrm{g}}$ & $50.0 \pm 0.4^{\mathrm{d}}$ \\
LTW & & $62.4 \pm 0.8^{\mathrm{a}}$ & $0.3 \pm 0.1^{\mathrm{h}}$ & $59.8 \pm 1.8^{\mathrm{a}}$ \\
\hline
\end{tabular}

Mean values $(n=3)$ followed by different lowercase letters within the same column indicate significant differences as determined by Fisher's test $(\mathrm{p}<0.05)$.

This fact would be consistent with the good interfacial properties of denatured proteins present in tofu-whey, in spite of the presence of calcium. Broadly, it is clear that the freezedrying is a better treatment to maintain the emulsifying properties of proteins present in both soy-whey and tofu-whey. The thermal drying of whey samples decreased the stability of resultant emulsions presumably by the loss of protein solubility. On the other hand, the h-LSW sample, obtained by heating of LSW in anhydrous conditions, exhibited a protein solubility lower than that of DSW sample. Nevertheless, h-LSW sample gave emulsions more stable than those prepared with DSW whatever the protein concentration. As was mentioned above, for h-LSW sample the $\mathrm{CH} / \mathrm{P}_{\mathrm{T}-\mathrm{TCA}}$ and $\mathrm{CH} /$ $\mathrm{P}_{\text {S-TCA }}$ were significantly higher than those of all other samples $(\mathrm{p}<0.05$, Table 1$)$, which would be indicative of protein glycosylation. The protein-carbohydrate interactions, through the Maillard reaction, electrostatic complexation or other mechanisms, improve the emulsifying properties and emulsion stability [Oliver et al., 2006; Matemu et al., 2009; Ray \& Rousseau, 2013; Kasran et al., 2013].

All emulsions showed a bimodal particle size distribution, with a main particle population above $10 \mu \mathrm{m}$ (results not shown). For $\mathrm{o} / \mathrm{w}$ emulsions prepared with aqueous dispersions $(0.5 \mathrm{~g}$ protein/100 mL), De Brouckere, volume-weighted mean diameters obtained from particle size distributions in the presence or absence of sodium dodecyl sulfate $\left(\mathrm{D}_{4,3+\mathrm{SDS}}\right.$ and $\mathrm{D}_{4,3-\mathrm{SDS}}$, respectively) are shown in Table 3 . Moreover,
TABLE $3 . \mathrm{D}_{43}$ mean diameters in the absence or presence of $10 \mathrm{~g} / \mathrm{L}$ sodium dodecyl sulfate $\left(\mathrm{D}_{4,3-\mathrm{SDS}}\right.$ and $\mathrm{D}_{4,3+\text { SDS }}$, respectively) and flocculation indices for $\mathrm{o} / \mathrm{w}$ emulsions prepared with different dried whey samples at equivalent protein concentration: $(0.5 \mathrm{~g} / 100 \mathrm{~mL})$.

\begin{tabular}{l|c|c|c}
\hline \multirow{2}{*}{ Sample } & \multicolumn{2}{|c|}{$\mathrm{D}_{4,3}(\mu \mathrm{m})$} & \multirow{2}{*}{$\begin{array}{c}\text { Flocculation index } \\
(\%)\end{array}$} \\
\cline { 2 - 4 } & - SDS & + SDS & $87.0 \pm 3.6^{\mathrm{a}}$ \\
\hline DSW & $172.6 \pm 2.5^{\mathrm{a}}$ & $92.3 \pm 1.7^{\mathrm{a}}$ & $55.0 \pm 2.5^{\mathrm{b}}$ \\
LSW & $70.6 \pm 2.6^{\mathrm{b}}$ & $45.5 \pm 2.1^{\mathrm{b}}$ & $12.6 \pm 2.6^{\mathrm{c}}$ \\
h-LSW & $40.0 \pm 1.5^{\mathrm{d}}$ & $34.5 \pm 1.2^{\mathrm{c}}$ & $55.5 \pm 2.6^{\mathrm{b}}$ \\
DTW & $52.9 \pm 2.2^{\mathrm{c}}$ & $34.1 \pm 0.6^{\mathrm{c}}$ & $10.7 \pm 0.6^{\mathrm{c}}$ \\
\hline
\end{tabular}

Mean values $(n=3)$ followed by different lowercase letters within the same column indicate significant differences as determined by Fisher's test $(\mathrm{p}<0.05)$.

flocculation indices were also reported (Eq. 2). It can be observed that $\mathrm{D}_{4,3-\mathrm{SDS}}$ evidenced an opposite tendency respect to that of $\mathrm{BS}_{0 \text {, bottom }}$ (Table 2); h-LSW, LTW and DTW emulsions exhibited the highest $\mathrm{D}_{4,3-\mathrm{SDS}}$ in concordance with their higher stability to gravitational separation. For the mentioned emulsions, with similar individual droplet sizes, the differences observed in stability ( $\mathrm{K}$ increasing in the order LTW $<$ DTW $<$ h-LSW, Table 2) rely on their flocculation degree. At $0.5 \mathrm{~g}$ protein/100 mL, LTW evidenced both the lowest flocculation index and the highest stability to gravitational separation. In comparing the flocculation indices for h-LSW, LSW and DSW emulsions, that prepared with h-LSW sample exhibited a relatively low value of this parameter $(\sim 13)$. This fact could be attributed to the presence of glycosylated proteins or protein linked to carbohydrates (Table 1). The steric repulsion associated to the presence of carbohydrates linked to adsorbed proteins, would be consistent with a low tendency to flocculation [Oliver et al., 2006].

On the other hand, the relative cream layer volume $(\mathrm{Vr}$, Eq. 4) was higher than 50\% for h-LSW and LTW emulsions regardless the protein concentration in the continuous phase. At $1.0 \mathrm{~g}$ protein/100 mL, Vr were $56.3 \%$ and $59.8 \%$, respectively (Table 2 ). If we take into account that the volume of dispersed oil was lower than $35 \%$ for all emulsions, then, the cream layer has a high degree of hydration [Palazolo et al., 2004]. The analysis of BS profiles in the upper zone of the measurement tube after a long quiescent storage ( $24 \mathrm{~h}$ to 7 days) gave additional information on emulsion stability. The kinetics of formation and destabilization of cream layer is shown in Figure $1 \mathrm{D}-\mathrm{F}$. The increase of $\mathrm{BS}_{\text {top }}$ at the beginning of storage is indicative of the gravitational separation process, in agreement with the clarification observed in the lower zone of tube (Figure 1A-C). After formation of cream layer, the noticeable increase in the particle concentration slowed down the upward particle movement, but the droplet aggregation processes such as coalescence and flocculation enhanced due to droplets came into close proximity. Indeed, the cream layer is less prone to coalescence when the short-range repulsive interactions between droplets and the thickness of the continuous phase around them (interstitial continuous 


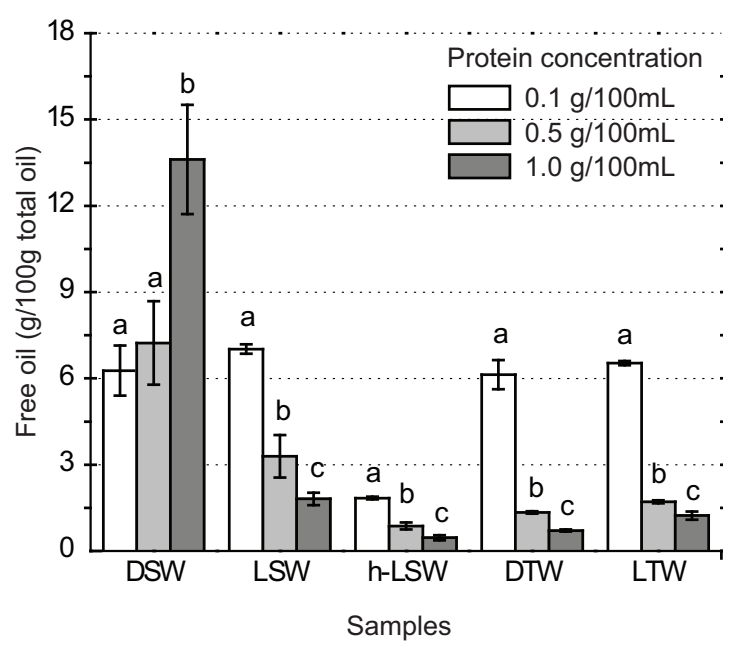

FIGURE 2. The content of free oil for $\mathrm{o} / \mathrm{w}$ emulsions prepared with different dried whey samples at equivalent protein concentration $(0.1$, 0.5 and $1.0 \mathrm{~g} / 100 \mathrm{~mL}$ ) after $24 \mathrm{~h}$ of quiescent storage. Values are the mean of three replicates $(n=3)$ and error bars indicate standard deviation. Mean values with different lowercase letters indicate significant differences between emulsions prepared with different protein concentration, as determined by Fisher's test $(\mathrm{p}<0.05)$.

phase) are high enough to avoid the prolonged contact under quiescent storage [van Aken, 2004; McClements, 2007]. For DSW and LSW emulsions the cream layer was quickly formed; then, it was destabilized due to $\mathrm{BS}_{\text {top }}$ decrease after $24 \mathrm{~h}$ of quiescent storage whatever the protein concentration (Figure 1D). As was mentioned above, at $0.1 \mathrm{~g}$ protein $/ 100 \mathrm{~mL}$ it is highly probable that the emulsifier concentration is limiting. Thus, the decrease of $\mathrm{BS}_{\text {top }}$ at long storage times would be attributed to coalescence. Indeed, the amount of free oil, generated by an advanced coalescence process was $>5 \mathrm{~g} / 100 \mathrm{~g}$ after $24 \mathrm{~h}$ (Figure 2). At higher protein concentration $(0.5$ and $1.0 \mathrm{~g} / 100 \mathrm{~mL})$, the decrease of $\mathrm{BS}_{\text {top }}$ can also be attributed to coalescence, especially for DSW emulsions, where an increase of free oil was effectively observed with increasing protein concentration $(\mathrm{p}<0.05)$. However, the decrease of $\mathrm{BS}_{\text {top }}$ would also be attributed to the spatial reordering of particles within the cream layer, such as the upward movement of greater particles without further release of oil. This would be valid for LSW sample, where the oiling off significantly decreased when protein concentration raised from 0.1 to $1.0 \mathrm{~g} / 100 \mathrm{~mL}$ ( $\mathrm{p}<0.05$, Figure 2). For $\mathrm{h}-\mathrm{LSW}$ emulsions, at $0.1 \mathrm{~g}$ protein $/ 100 \mathrm{~mL}$, the cream layer showed the highest stability, in clear agreement with its low free oil content $(<2 \mathrm{~g} / 100 \mathrm{~g}$, Figure 2). At the highest protein concentration, h-LSW, LTW and DTW emulsions showed a similar stability after a prolonged storage, according to high hydration degree of their cream layers (Figure 1F, Table 2). Thus, their adsorbed proteins would form viscoelastic membranes, which provide stronger short-range repulsive interactions between droplets avoiding the exclusion of interstitial continuous phase [McClements, 2007].

\section{Physicochemical characterization of isolated proteins from lyophilized whey samples}

In the previous section, it was observed that the emulsifying properties of whey samples obtained by freeze-drying were higher than those prepared by thermal drying. Hence, it was decided to isolate the proteins from lyophilized whey samples (LSW, h-LSW and LTW) in order to comparatively evaluate their emulsifying properties. From the analysis of proximate composition it can be seen that the utilization of cold acetone at low temperature induced the simultaneous precipitation of protein and carbohydrates (Table 4). Nevertheless, the crude protein content for all protein samples was higher than that of carbohydrates. In addition, for h-LSW-P sample, carbohydrates content, $\mathrm{CH} / \mathrm{P}_{\mathrm{T}-\mathrm{TCA}}, \mathrm{CH} / \mathrm{P}_{\mathrm{S}-\mathrm{TCA}}$ and protein denaturation degree were significantly higher than those of LSW-P $(\mathrm{p}<0.05)$. On the other hand, LTW-P sample showed the highest contents of ash and calcium $(p<0.05)$, in agreement with the high mineral content of lyophilized tofu-whey (Table 1). With regard to the protein aggregation, the protein solubility significantly decreased in the order LTW-P > LSW-P > h-LSW-P (p<0.05) (Table 4).

\section{Emulsifying properties of isolated proteins from lyophilized whey samples}

Figure $3 \mathrm{~A}-\mathrm{C}$ shows the gravitational separation kinetic for $\mathrm{o} / \mathrm{w}$ emulsions prepared with isolated proteins at equivalent crude protein concentration $(0.1,0.5$ and $1.0 \mathrm{~g} / 100 \mathrm{~mL})$. Overall, during the first hour of quiescent storage, the upward movement of particles was evident for all emulsions. Besides,

TABLE 4. Chemical composition, protein solubility and protein denaturation degree for isolated protein samples. Carbohydrate/protein mass ratio was obtained for the total fraction $\left(\mathrm{CH} / \mathrm{P}_{\mathrm{T}-\mathrm{TCA}}\right)$ and soluble fraction $\left(\mathrm{CH}-\mathrm{P}_{\mathrm{S}-\mathrm{TCA}}\right)$ (see Materials and Methods section).

\begin{tabular}{|c|c|c|c|c|c|c|c|c|}
\hline \multirow{3}{*}{ Samples } & \multicolumn{6}{|c|}{ Chemical composition } & \multirow{3}{*}{$\begin{array}{l}\text { Protein } \\
\text { solubility } \\
\text { (g/100 g total } \\
\text { protein) }\end{array}$} & \multirow{3}{*}{$\begin{array}{l}\text { Protein } \\
\text { denaturation } \\
\text { degree } \\
(\%)\end{array}$} \\
\hline & \multirow{2}{*}{$\begin{array}{l}\text { Crude protein } \\
\qquad(\mathrm{N} \times 6.25) \\
(\mathrm{g} / 100 \mathrm{~g})\end{array}$} & \multirow{2}{*}{$\begin{array}{c}\text { Total } \\
\text { carbohydrates } \\
(\mathrm{g} / 100 \mathrm{~g})\end{array}$} & \multirow[t]{2}{*}{$\begin{array}{c}\text { Ash } \\
(\mathrm{g} / 100 \mathrm{~g})\end{array}$} & \multirow[t]{2}{*}{$\begin{array}{l}\text { Calcium } \\
(\mathrm{g} / 100 \mathrm{~g})\end{array}$} & \multicolumn{2}{|c|}{$\begin{array}{c}\text { Carbohydrates/ } \\
\text { protein mass ratio } \\
\text { (mg CH/100 mg protein) }\end{array}$} & & \\
\hline & & & & & $\mathrm{CH} / \mathrm{P}_{\mathrm{TTCA}}$ & $\mathrm{CH} / \mathrm{P}_{\text {S-TCA }}$ & & \\
\hline LSW-P & $54.2 \pm 2.1^{\mathrm{a}}$ & $27.2 \pm 0.7^{\mathrm{b}}$ & $11.2 \pm 0.8^{b}$ & $1.09 \pm 0.01^{\mathrm{b}}$ & $3.3 \pm 0.3^{c}$ & $4.0 \pm 0.4^{c}$ & $64.2 \pm 0.5^{\mathrm{b}}$ & $33.4^{\mathrm{b}}$ \\
\hline h-LSW-P & $57.1 \pm 2.6^{\mathrm{a}}$ & $31.2 \pm 0.1^{\mathrm{a}}$ & $8.3 \pm 0.8^{c}$ & ND & $18.7 \pm 3.4^{\mathrm{a}}$ & $34.4 \pm 3.2^{\mathrm{a}}$ & $45.5 \pm 0.5^{\mathrm{c}}$ & $100^{\mathrm{a}}$ \\
\hline LTW-P & $40.5 \pm 1.1^{\mathrm{b}}$ & $29.7 \pm 1.8^{\mathrm{b}}$ & $16.3 \pm 1.0^{\mathrm{a}}$ & $6.96 \pm 0.01^{\mathrm{a}}$ & $7.8 \pm 1.5^{\mathrm{b}}$ & $8.7 \pm 0.1^{b}$ & $79.9 \pm 1.3^{\mathrm{a}}$ & $100^{\mathrm{a}}$ \\
\hline
\end{tabular}

Mean values $(n=3)$ followed by different lowercase letters within the same column indicate significant differences as determined by Fisher's test $(\mathrm{p}<0.05)$.

ND: not determined. 
the stability to gravitational separation increased with increasing protein concentration in the continuous phase. In comparing the behavior of individual protein samples, at low and intermediate protein concentration $(0.1$ and $0.5 \mathrm{~g} / 100 \mathrm{~mL})$, the stability decreased in the order LTW-P $>$ LSW-P $>$ h-LSW-P (Table 5). At $1.0 \mathrm{~g}$ protein $/ 100 \mathrm{~mL}$, no decrease of $\mathrm{BS}_{\text {bottom }}$ was seen for LSW-P and LTW-P emulsions after $35 \mathrm{~min}$ of storage, according to their high stability to gravitational separation $\left(\mathrm{K}<0.4 \mathrm{~min}^{-1}\right)$ (Figure $3 \mathrm{C}$, Table 5).

In addition, the kinetic of formation and destabilization of cream layer is shown in Figure 3 C-D. At low protein concentration, the cream layer of LTW-P emulsions was formed after 20 min of quiescent storage, according to increase of particle concentration in the upper part of measurement cell. In contrast, for LSW-P emulsions, the cream layer showed the lowest stability: immediately after its formation, $\mathrm{BS}_{\text {top }}$ progressively decreased as a function of time (Figure 3C). This fact would be attributed to droplet coalescence. When free oil content was determined after $24 \mathrm{~h}$ of quiescent storage, LSW-P emulsions showed the highest release of oil $(>4 \mathrm{~g} / 100 \mathrm{~g}$,
Table $5, \mathrm{p}<0.05)$. At intermediate and high protein concentration in the continuous phase $(0.5$ and $1.0 \mathrm{~g} / 100 \mathrm{~mL})$, all emulsions evidenced a similar behavior: the cream layers were fairly stable after long storage times. The increase of $\mathrm{Vr}$, especially at the highest protein concentration was consistent with a high degree of hydration of cream layer. As was mentioned above, when droplets came into close proximity in the upper part of tube after creaming, the tendency to coalescence can be noticeably reduced if the cream layers are hydrated [van Aken, 2005; McClements, 2007]. This fact was in clear agreement with very low free oil content for emulsions prepared with the isolated proteins at the highest protein concentration $(<0.7 \mathrm{~g} / 100 \mathrm{~g}$, Table 5$)$.

Interestingly, in comparing the stability of $\mathrm{o} / \mathrm{w}$ emulsions prepared with lyophilized whey samples and their isolated proteins, it can be observed that the isolation of proteins by precipitation with cold acetone had a positive impact on emulsion stability (Tables 2 and 5). For emulsions prepared with isolated proteins, the increase of stability to gravitational separation was more evident with increasing protein concen-
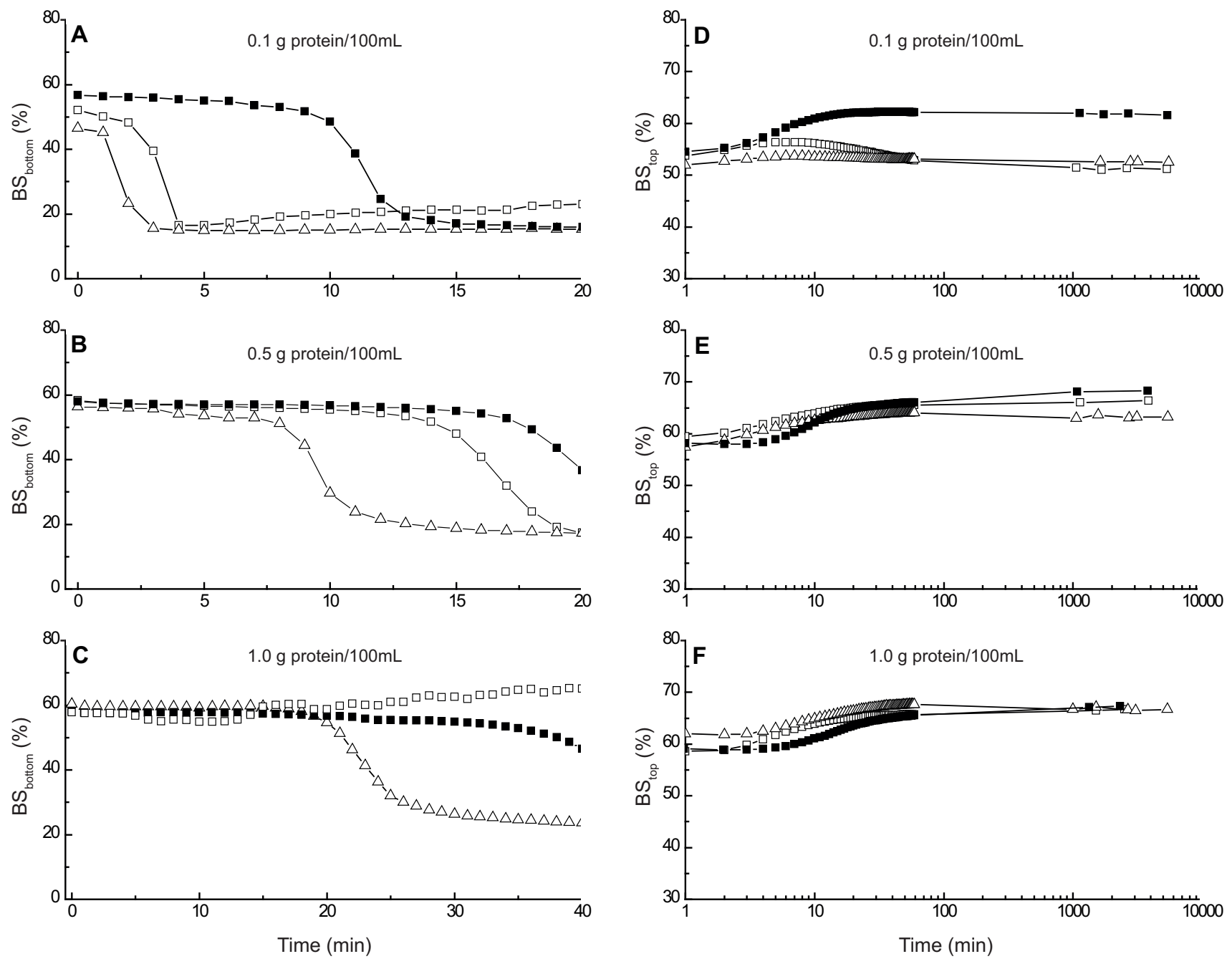

FIGURE 3. Creaming-flocculation kinetic ( $\mathrm{BS}_{\text {bottom }}$, zone $15-17 \mathrm{~mm}$ as a function of time) for o/w emulsions prepared with different isolated protein samples at equivalent protein concentration $(\mathrm{A}, \mathrm{B}, \mathrm{C})$. Kinetic of formation and destabilization of cream layer (BS ${ }_{\text {top }}$, zone $60-62 \mathrm{~mm}$, as a function of time) for o/w emulsions prepared with different dried whey samples at equivalent protein concentration (D,E,F). 
TABLE 5. Initial mean $(\mathrm{t}=0)$ values of backscattering $\left(\mathrm{BS}_{0, \mathrm{t}}\right.$, zone $\left.15-17 \mathrm{~mm}\right)$, gravitational separation kinetic constant $(\mathrm{K})$, relative cream layer volume $(\mathrm{Vr})$ and the content of free oil for $\mathrm{o} / \mathrm{w}$ emulsions prepared with different isolated protein samples at equivalent protein concentration in the continuous phase.

\begin{tabular}{|c|c|c|c|c|c|}
\hline Sample & $\begin{array}{c}\text { Protein } \\
(\mathrm{g} / 100 \mathrm{~mL}) \\
\end{array}$ & $\begin{array}{c}\mathrm{BS}_{0, \text { bottom }} \\
(\%)\end{array}$ & $\begin{array}{c}\mathrm{K} \\
\left(\mathrm{min}^{-1}\right) \\
\end{array}$ & $\begin{array}{l}\mathrm{Vr} \\
(\%) \\
\end{array}$ & $\begin{array}{c}\text { Free oil } \\
\text { (g/100 g total oil) }\end{array}$ \\
\hline LSW-P & & $52.1 \pm 0.6^{\mathrm{d}}$ & $5.4 \pm 0.3^{b}$ & $54.6 \pm 3.8^{\mathrm{b}}$ & $4.8 \pm 0.2^{\mathrm{A}}$ \\
\hline h-LSW-P & 0.1 & $46.5 \pm 1.4^{\mathrm{e}}$ & $10.8 \pm 0.5^{\mathrm{a}}$ & $52.7 \pm 3.7^{\mathrm{b}}$ & $2.3 \pm 0.5^{\mathrm{B}}$ \\
\hline LTW-P & & $55.8 \pm 0.4^{\mathrm{c}}$ & $1.6 \pm 0.1^{\mathrm{c}}$ & $55.1 \pm 3.9^{\mathrm{b}}$ & $1.1 \pm 0.3^{\mathrm{C}}$ \\
\hline LSW-P & & $58.3 \pm 0.4^{\mathrm{b}}$ & $1.0 \pm 0.1^{\mathrm{d}}$ & $62.7 \pm 2.5^{\mathrm{a}}$ & $1.1 \pm 0.2^{\mathrm{A}}$ \\
\hline h-LSW-P & 0.5 & $56.4 \pm 0.4^{c}$ & $1.7 \pm 0.1^{\mathrm{c}}$ & $64.1 \pm 3.3^{\mathrm{a}}$ & $1.2 \pm 0.3^{\mathrm{A}}$ \\
\hline LTW-P & & $57.9 \pm 0.4^{\mathrm{b}}$ & $0.8 \pm 0.1^{\mathrm{d}}$ & $54.4 \pm 3.1^{\mathrm{b}}$ & $0.5 \pm 0.4^{\mathrm{A}}$ \\
\hline LSW-P & & $57.8 \pm 0.1^{\mathrm{b}}$ & $0.1 \pm(<0.1)^{\mathrm{f}}$ & $61.6 \pm 1.4^{\mathrm{a}}$ & $0.6 \pm 0.1^{\mathrm{A}}$ \\
\hline h-LSW-P & 1.0 & $60.3 \pm 0.1^{\mathrm{a}}$ & $0.6 \pm 0.1^{\mathrm{e}}$ & $63.8 \pm 0.6^{\mathrm{a}}$ & $0.6 \pm 0.1^{\mathrm{A}}$ \\
\hline LTW-P & & $58.2 \pm 0.1^{\mathrm{b}}$ & $0.3 \pm(<0.1)^{\mathrm{f}}$ & $61.5 \pm 0.6^{\mathrm{a}}$ & $0.5 \pm 0.2^{\mathrm{A}}$ \\
\hline
\end{tabular}

Mean values $(n=3)$ of free oil content followed by different uppercase letters within the same column, at the same protein concentration, indicate significant differences as determined by Fisher's test $(\mathrm{p}<0.05)$. Mean values $(n=3)$ followed by different lowercase letters within the same column indicate significant differences as determined by Fisher's test $(\mathrm{p}<0.05)$.

tration; $\mathrm{K}$ was lower than $2 \mathrm{~min}^{-1}$ and $1 \mathrm{~min}^{-1}$ at 0.5 and $1.0 \mathrm{~g}$ protein/100 $\mathrm{mL}$, respectively (Table 5). Although the protein solubility of isolated proteins was lower respect to that of lyophilized whey samples, the decrease of carbohydrate content and other substances interfering with the interfacial properties after the treatment with the organic solvent, would be consistent with the increase of emulsion stability. This fact was especially evident in comparing the emulsifying properties of LSW-P and LSW emulsions. At $0.5 \mathrm{~g}$ protein/100 mL, $\mathrm{D}_{4,3}$ - sDS was almost two times lower for the emulsion prepared with the isolated protein. Besides, a noticeable difference in flocculation degree was evidenced: for LSW-P emulsions, no stable flocs were detected in the measurement conditions (Tables 3 and 6). This difference has a marked influence on the stability of both emulsions to gravitational separation (Tables 2 and 5). Moreover, unlike LSW sample, LSW-P contains partially denatured proteins (Tables 1 and 4), which would improve the emulsifying properties of this last sample. On the other hand, for h-LSW-P and h-LSW emulsions, the differences in stability were less evident. At 0.5 g protein $/ 100 \mathrm{~mL}$, the droplet size and degree of flocculation were similar for

TABLE 6. $\mathrm{D}_{43}$ mean diameters in the absence or presence of $10 \mathrm{~g} / \mathrm{L}$ sodium dodecyl sulfate $\left(\mathrm{D}_{4,3-\mathrm{SDS}}\right.$ and $\mathrm{D}_{4,3+\mathrm{SDS}}$, respectively) and flocculation indices for $\mathrm{o} / \mathrm{w}$ emulsions prepared with different isolated protein samples at equivalent protein concentration $(0.5 \mathrm{~g} / 100 \mathrm{~mL})$.

\begin{tabular}{l|c|c|c}
\hline \multirow{2}{*}{ Sample } & \multicolumn{2}{|c|}{$\mathrm{D}_{4,3}(\mu \mathrm{m})$} & $\begin{array}{c}\text { Flocculation index } \\
(\%)\end{array}$ \\
\cline { 2 - 3 } & - SDS & + SDS & $0.6 \pm 0.1^{\mathrm{c}}$ \\
\hline LSW-P & $39.6 \pm 1.1^{\mathrm{b}}$ & $39.4 \pm 1.2^{\mathrm{b}}$ & $12.0 \pm 1.4^{\mathrm{a}}$ \\
h-LSW-P & $48.0 \pm 1.4^{\mathrm{a}}$ & $42.9 \pm 1.3^{\mathrm{a}}$ & $9.2 \pm 0.3^{\mathrm{b}}$ \\
\hline
\end{tabular}

Mean values $(n=3)$ followed by different lowercase letters within the same column indicate significant differences as determined by Fisher's test $(\mathrm{p}<0.05)$. both emulsions (Tables 3 and 6). Although stability to gravitational separation slightly improved when the emulsions were prepared with isolated proteins, the protein glycosylation enhanced the coalescence stability, in agreement with the low free oil content regardless the sample concentration (Figure 2, Table 5). Finally, for LTW-P and LTW emulsions the stability to gravitational separation and coalescence after long storage times exhibited the least differences. At $0.5 \mathrm{~g}$ protein $/ 100 \mathrm{~mL}$, the droplet size and flocculation degree was similar for both emulsions (Tables 3 and 6). This result is not surprising; as a consequence of industrial hydrothermal treatments carried out during the obtaining of tofu, tofu-whey liquid is composed by totally denatured proteins [Sobral et al., 2010]. Hence, the conformational state of denatured proteins would be slightly affected by the experimental procedures of preparation of both samples. Although LTW-P was enriched in proteins after treatment with cold acetone, this sample evidenced a slight decrease $(\sim 5 \%)$ of protein solubility respect to that of LTW (Tables 1 and 4).

\section{CONCLUSIONS}

In this paper, the comparative analysis of emulsifying properties of dried soy-whey, dried tofu-whey and their isolated proteins was assessed. Although in all cases, the increase of protein concentration in the continuous phase enhanced the emulsion stability to gravitational separation and coalescence, at equivalent protein concentration, lyophilized whey samples exhibited a higher ability to form and stabilize emulsions respect to that of thermally-dried ones. This fact was especially evident for samples obtained from soy-whey. In this context, the proteins present in tofu-whey would be less affected by drying treatments due to their both total denaturation degree and less sensitivity to aggregation. In addition, the heating of lyophilized soy-whey samples in anhydrous conditions, which ensures the inactivation of trypsin inhibitors, improved their emulsifying properties presumably due 
to protein glycosylation. This effect counteracted the loss of protein solubility attributed to thermal treatment. Besides, at equivalent protein concentration in the aqueous phase, the isolation of proteins from lyophilized whey-samples by treatment with cold acetone improved their emulsifying properties. Again, this improvement was more pronounced for samples obtained from soy-whey regardless the decrease of protein solubility (15-20\%). The conformational state of fully denatured tofu-whey proteins would less affected by the treatment with organic solvent during the preparation of isolated proteins. This fact would be associated with a slight reduction of protein solubility after protein isolation, as was mentioned above.

In this paper we have demonstrated that dried soy-whey and dried tofu-whey samples have potential application as emulsifiers in the food industry, contributing to exploitation of liquid soy-whey and tofu-whey.

\section{ACKNOWLEDGEMENTS}

The authors of this work wish to thank Soyana S.H. (General San Martín, Provincia de Buenos Aires, Argentina) for kindly providing us the tofu-whey liquid samples.

\section{RESEARCH FUNDING}

This study was funded by grants from Universidad Nacional de Quilmes (PUNQ 53/1037), Consejo Nacional de Investigaciones Científicas y Técnicas (CONICET, PIP 2012 -2014 N $\mathrm{N}^{\circ} 1220110100398$ ) and Agencia Nacional de Promoción Científica y Tecnológica (ANPCyT, PICT 2014-1267).

\section{CONFLICT OF INTEREST}

Authors declare no conflict of interest

\section{REFERENCES}

1. AOAC. Official Methods of Analysis of AOAC International. Sixteen Edition, 3rd Revision, Volume II., 1997, AOAC International, Gaithersburg, Maryland, USA.

2. Benedetti S., Prudêncio E.S., Nunes G.L., Guizoni K., Fogaça L.R., Petrus J.C.C., Antioxidant properties of tofu whey concentrate by freeze concentration and nanofiltration processes. J. Food Eng., 2015, 160, 49-55.

3. Chen Y., Xu Z., Zhang C., Kong X., Hua Y., Heat-induced inactivation mechanisms of Kunitz trypsin inhibitor and BowmanBirk trypsin inhibitor in soymilk processing. Food Chem., 2014, 154, 108-116.

4. Huang H., Kwok K-C., Liang H.H., Inhibitory activity and conformation changes of soybean trypsin inhibitors induced by ultrasound. Ultrason. Sonochem., 2008, 15, 724-730.

5. Jafari S.M., Assadpoor E., He Y., Bhandari B., Re-coalescence of emulsion droplets during high-energy emulsification. Food Hydrocolloid., 2008, 22, 1191-1202.

6. Kao F.J., Su N. W., Lee M.S., Effect of calcium concentration in soymilk on the microstructure of firm tofu and the protein constitutions in tofu whey. J. Agric. Food Chem., 2003, 51, 6211-6216.
7. Kasran M., Cui S.W., Goff H.D., Emulsifying properties of soy whey protein isolate-fenugreek gum conjugates in oil-in-water emulsion model system. Food Hydrocolloid., 2013, 30, 691-697.

8. Lajolo F.M., Genovese M.I., Nutritional significance of lectins and enzyme inhibitors from legumes. J. Agric. Food Chem., 2002, 50, 6592-6598.

9. Li R., Wu Z., Wang Y., Liu W., Pilot study of recovery of whey soy proteins from soy whey wastewater using batch foam fractionation. J. Food Eng., 2014, 142, 201-209.

10. Liu W., Zhang H.X., Wu Z.L., Wang Y.J., Wang L.J., Recovery of isoflavones aglycones from soy whey wastewater using foam fractionation and acidic hydrolysis. J. Agric. Food Chem., 2013, 61, 7366-7372.

11. Marshall M.R., Ash analysis. 2009, in: Food Analysis. Fourth Edition (ed. S. Nielsen). Springer, New York, pp. 105-116.

12. Matemu A.O., Kayahara H., Murasawa H., Nakamura S., Importance of size and charge of carbohydrate chains in the preparation of functional glycoproteins with excellent emulsifying properties from tofu whey. Food Chem., 2009, 114, 1328-1334.

13. McClements D.J., Protein-stabilized emulsions. Curr. Opin. Colloid Int. Sci., 2004, 9, 305-313.

14. McClements D.J., Critical reviews of techniques and methodologies for characterization of emulsion stability. Crit. Rev. Food Sci. Nutr., 2007, 47, 611-649.

15. Meng S., Chang S., Gillen A.M., Zhang Y., Protein and quality analyses of accessions of USDA soybean germplasm collection for tofu production. Food Chem., 2016, 213, 31-39.

16. Mengual O, Meunier G., Cayré I., Puech K., Snabre P., Turbiscan MA 2000: multiple light scattering measurements for concentrated emulsion and suspension instability analysis. Talanta, 1999, 50, 445-456.

17. Oliver C.M., Melton L.D., Stanley R.A., Creating proteins with novel functionality via the Maillard reaction. A review. Crit. Rev. Food Sci. Nutr., 2006, 46, 337-350.

18. Palanuwech J., Potineni R., Roberts R.F., Coupland J.N., A method to determine free fat in emulsions. Food Hydrocolloid., 2003, 17, 55-62.

19. Palazolo G.G., Sobral P.A., Wagner J.R., Dehydrated tofu whey as cryoprotectant in protein-stabilized oil-in-water emulsions. LWT-Food Sci. Technol., 2013, 50, 773-781.

20. Palazolo G.G., Sorgentini D.A., Wagner J.R., Emulsifying properties and surface behavior of native and denatured whey soy proteins in comparison with other proteins. Creaming stability of oilin-water emulsions. J. Am. Oil Chem. Soc., 2004, 81, 625-632.

21. Ray M., Rousseau D., Stabilization of oil-in-water emulsions using mixtures of denatured soy whey proteins and soluble soybean polysaccharides. Food Res. Int., 2013, 52, 298-307.

22. Shen Y-R., Kuo M-I., Effects of different carrageenan types on the rheological and water holding properties of tofu. LWT-Food Sci. Technol., 2017, 78, 122-128.

23. Singh A. Banerjee R., Peptide enriched functional food adjunct from soy whey: a statistical optimization study. Food Sci. Biotechnol., 2013, 22, 65-71.

24. Sobral P.A., Palazolo G.G., Wagner J.R., Thermal behavior of soy protein fractions depending on their preparation methods, individual interactions, and storage conditions. J. Agric. Food Chem., 2010, 58, 10092-10100.

25. Sobral P. A., Wagner J. R. Thermal properties of soybean whey and its proteins. 2007, in: Functional Properties of Food Com- 
ponents (ed. C.E. Lupano). Research Signpost, Kerala, India, pp. $57-76$.

26. Stoscheck C.M., Quantitation of protein. Method Enzymol., 1990, 182, 50-68.

27. Thanasukarn P., Pongsawatmanit R., McClements D. J., Influence of the emulsifier type on freeze-thaw stability of hydrogenated palm oil-in-water emulsions. Food Hydrocolloid., 2004, 18, 1033-10043.

28. Vagadia B.H., Vanga S. K., Raghavan V., Inactivation method of soybean trypsin inhibitor. A review. Trends Food Sci. Technol., 2017, 64, 115-125.
29. van Aken G.A. Coalescence mechanisms in protein-stabilized emulsions. 2004, in: Food Emulsions. Fourth edition revised and expanded (eds. S.E. Friberg, K. Larsson, J. Sjöblom). Marcel Dekker, Inc., New York, pp. 310-336.

30. van der Ven C., Matser A.M., van den Berg R.M., Inactivation of soybean trypsin inhibitors and lipoxygenase by high-pressure processing. J. Agric. Food Chem., 2005, 53, 1087-1092.

Submitted: 28 September 2017. Revised: 5 December 2017. Accepted: 4 January 2018. Published on-line: 28 March 2018. 